\title{
Plaučių policistozé
}

Reikšminiai žodžiai: plaučiu policistozė, vaikai, suaugusieji.

Santrauka. Plaučių policistozè - vienas dažniausių plaučių sklaidos sutrikimų. Paprastai ši sklaidos yda diagnozuojama naujagimystės ar kūdikystės laikotarpiu, o suaugusiesiems labai retai. Todèl suaugusiujų gydytojai rečiau susiduria su šia patologija ir ja sergančių pacientų priežiūra. Straipsnyje pateikiami esminiai plaučių policistozės diagnostikos, gydymo ir priežiūros aspektai (tiek vaikams, tiek suaugusiesiems).

\section{IVADAS}

Plaučiu sklaidos sutrikimai nėra dažni. Pirmieji, susiduriantys su igimtais organu sutrikimais (taip pat ir plaučių), jụ keliamomis sveikatos problemomis, yra vaiku gydytojai. Nemaža dalis sergančiu šiomis ligomis taip ir nesulaukia suaugusiụju amžiaus. Tačiau pasitaiko atvejų, kai liga ilgus metus buvusi nebyli ar nediagnozuota, pirmą kartą pasireiškia būtent vyresniems žmonėms, vis dažniau suaugusiụjuc amžiaus sulaukiama dèl ilgèjančios gyvenimo trukmės gerejjant sveikatos priežiūros paslaugoms. Dèl suaugusiu pacientú gydytojų natūraliai mažesnio budrumo igimtu ligu atžvilgiu, pastarosios taip ir gali likti tinkamai neidentifikuotos arba ju priežiūra gali būti komplikuota. Vienas dažniausių plaučiu sklaidos sutrikimu yra plaučiu policistozė [1]. Literatūros duomenimis, plaučiu policistoze serga 1 iš 11000-35000 gyvų gimusiujjų [1], suaugusiụjų amžių pasiekia ženkliai mažiau (tikslios statistikos nèra dèl kelių pagrindinių priežasčiụ: mažo pacientuc skaičiaus, riboto publikuojamų klinikinių atvejų skaičiaus, besimptomių ligos atvejų). Siekiant maksimaliai pagerinti plaučiu policistoze sergančio asmens priežiūrą ar, ịtarus ligą, ją tinkamai diagnozuoti, verta prisiminti esminius ligos aspektus.

\section{ETIOLOGIJA IR EPIDEMIOLOGIJA}

Plaučiu policistozè yra igimta liga. Paprastai nustatoma dar prenataliniu ar naujagimystès laikotarpiu, tačiau gali būti diagnozuojama ir vyresniems vaikams ar suaugusiems asmenims atsitiktinai radiologiškai pastebèjus plaučių policistozei būdingus plaučiu audinio pokyčius arba ligą nustačius kaip pasikartojančios krūtinès ląstos infekcijos priežastį. Plaučiu policistozès etiologija nèra aiški. Prenatalinis mirštamumas, literatūroje skelbiamais duomenimis, siekia 9-49 proc. [2, 3, 4]. Naujagimystès laikotarpiu miršta apie 25-30 proc. naujagimių, kuriems pasireiškia plaučiu policistozės simptomai, tačiau ị ší apskaičiuotą procentą neittraukiami besimptomiai ligoniai, kuriems liga diagnozuojama vyresniems [2]. Taigi suaugusiụjų amžių pasiekia tik mažesnioji dalis asmenų. Atliktoje anglu kalba prieinamos literatūros apžvalgoje minima, kad analizuojant iki 2015 metų vasario mènesio publikuotus duomenis, pavyko rasti tik 47 aprašytus plaučiu policistozès atvejus vyresniems kaip 17 metu asmenims [5]. Ligos nustatymas suaugusiesiems yra gan retas reiškinys, nes paprastai ji nustatoma per pirmuosius gyvenimo metus (3-10 proc. naujagimių, kuriems nepasireiškè simptomai naujagimystès laikotarpiu, tačiau buvo pastebèti plaučiu policistozei būdingi plaučiu pažeidimai antenataliniu periodu) $[2,3,4]$, o vidutiniškai iki 2 metu amžiaus simptomai pasireiškia apytiksliai 18 pacientuc iš $21[2,6]$. Vyriausias suaugusysis, kuriam diagnozuota plaučiu policistozé, yra 35 metu [7].

Šis plaučiu sklaidos sutrikimas kiek dažniau diagnozuojamas vyrams nei moterims [8].

\section{PATOFIZIOLOGIJA}

Plaučių policistozè pasireiškia cistomis ar solidinemis masèmis ribotame plaučiu plote $[9,10]$. Vertinant patologinius rezekuoto plaučiu audinio pokyčius, plaučiu policistozės atveju pastebima padidéjusi ląsteliu proliferacija (adenomatozinè bronchioliu proliferacija) ir sumažéjusi ju apoptozé, alveoliu sąskaita formuojasi cistos [2]. Tačiau néra nustatytų tiksliụ plaučiu policistozès formavimosi mechanizmų. Nèra aiškus ir paveldejjimo ryšys. Tačiau ši liga siejama su chromosomu pokyčiais: 18 chromosomos trisomija ir paveldima inkstu displazija [11]. Manoma, kad prie plaučiu policistozės vystymosi prisideda mutacijos, sutrikdančios TTF-1 (angl. thyroid transcription factor-1) veikla (TTF-1 randama bronchų ir alveoliu epitelyje; reguliuoja plaučiu epitelio diferenciaciją) [12]. Taip pat pastebèta, kad plaučių policistozès pažeistuose kvèpavimo takuose didele HoxB5 (Homeobox baltymų) raiška, palyginti su sveikụjų plaučiu audiniu. Paprastai HoxB5 genas koduoja baltymą, veikianti kaip specifinès sekos transkripcijos faktoriu ir taip reguliuojantį normalu plaučiu vystymąsi. Taigi padaryta prielaida, kad neịprasta HoxB5 geno raiška taip pat gali būti atsakinga už plaučiu policistozès vystymąsi, nes sukelia netipišką kvèpavimo takų šakojimąsi [13]. Buvo tirtas ir kitu augimo faktorių, pvz., mezenchimines trombocitu kilmès augimo faktoriaus- $\mathrm{BB}$, vaidmuo plaučiu policistozès patogenezeje [2], bet del mažo tiriamujjų skaičiaus neginčijamos išvados nesuformuluotos.

1977 m. Stockeris plaučiu policistozès sukeliamus pažeidimus suskirstè $\mathfrak{z} 3$ tipus (klasifikacija grịsta cistụ dydžiu, ju skaičiumi ir patologiniais pokyčiais) $[9,14,2]$ : I tipui būdinga daugybè didelių $(2-10 \mathrm{~cm})$ cistų, iš kurių bent viena yra vyraujanti, mažesnès cistos išsidèsto išilgai jos periferijoje. Cistų sienelès išklotos 
virpamuoju pseudostratifikuotu stulpiniu epiteliu, po epiteliu yra elastinis jungiamasis audinys, lygieji raumenys ir fibrovaskulinis jungiamasis audinys, iskaitant kremzles. I tipas yra labiausiai paplitęs ir susijęs su gera prognoze [12]. II tipo policistozei būdingos mažos ir labai panašaus dydžio cistos (0,5-2 cm; paprastai mažesnès kaip 1 cm skersmens). Cistos išklotos kubiniu pereinančiu $\mathfrak{i}$ stulpinį epiteliu ir turi ploną fibroraumeninę sienelę. Šis tipas sudaro kiek daugiau nei 40 proc. plaučiu policistozès atvejų. Pagal Stockeri, net apie 60 proc. II tipo plaučiu policistozès atvejų susiję su kitomis igimtomis anomalijomis (ypač inkstuc ageneze, tačiau gali būti ir širdies, skeleto, žarnyno anomalijos, papildomos plaučių skilties sekvestracija), kurios gali turèti itakos ligos prognozei [12]. III tipas sudaro mažiau nei 5 proc. visų ligos atvejų [2]. Jam būdinga dauginès mikrocistos, kurių skersmuo mažesnis nei $0,5 \mathrm{~cm}$, ir tai, kad pažeidžiamas didelis plaučiu plotas, paprastai ne mažiau kaip visa plaučio skiltis [12] (1993 m. Adzickas pateikè plaučių cistuc klasifikaciją - mikrocistomis vadinamos mažesnio nei $5 \mathrm{~mm}$ skersmens cistos, paprastai susijusios su vaisiaus vandene ir jos yra blogos prognozès ženklas. Makrocistos - cistos, kurių skersmuo didesnis kaip $5 \mathrm{~mm}$, paprastai nesusijusios su vandene ir turinčios gerą prognozę [2]).

Atsiradus pakeitimų plaučių policistozès klasifikacijoje, be trijų pagrindinių išvardytų tipų, remiantis plaučių pažeidimo vieta - nuo tracheobronchiniu iki acinarinių struktūruc - skiriami dar du tipai, (tačiau radiologiškai identifikuojami tik trys pagrindiniai): 0 tipas - cistuc nèra arba jos labai smulkios $(<0,5 \mathrm{~cm})$, būdinga acinarinè atrezija (tracheobronchinis defektas), 0 tipas nesuderinamas su gyvybe; ir IV tipas, kuriam būdingos didelès iki $10 \mathrm{~cm}$ dydžio - cistos (daugybè cistų, linija išsidèsčiusių palei išplonejjusị epitelị (alveolių defektas))[9, 2] . Dažnai ligos tipai persipina [5].

Beveik 44 proc. iš aprašytų plaučių policistozès atvejų pirmiausiai pažeidžiamaviena plaučiuc pusè, konkrečiau apatinė plaučiuc skiltis [5, 13]. Dideli plaučių audinio pažeidimai gali būti susiję su vaisiaus vandene (net 40 proc. atvejų) ir yra blogos prognozès ženklas. Manoma, kad vandenè atsiranda dèl apatinès tuščiosios venos suspaudimo, sutrinka veninė kraujotaka, mažeja minutinis širdies tūris ir gereja skysčiuc prasiveržimas. Dèl šios būklès vaisius gali žūti, todèl, siekiant išgelbèti jo gyvybę, gali būti sukeliamas priešlaikinis gimdymas [15]. Kitas svarbus prenatalinis veiksnys - sutrikęs plaučių augimas. Dèl to plaučių hipoplazija naujagimiui po gimimo gali sukelti respiracini distresą. Polihidramnionas taip pat susijęs su cistiniu plaučių pažeidimu ir yra rezultatas padidejusio intratorakalinio spaudimo, sąlygojančio stemplès suspaudimą ir sunkesni ryjimą [16].

\section{KLINIKA}

Dažniausiai plaučių policistozè pasireiškia gyvybei pavojingu respiracinio distreso sindromu dar naujagimysteje ir nuolat pasikartojančiomis pneumonijomis, plaučiu abscesais ar kitomis krūtinès ląstos infekcijomis vyresniame amžiuje (tiek vaikų, tiek suaugusiujuc) arba gali neturèti jokios klinikinès išraiškos ir būti atsitiktinis radiologinis radinys.

Respiracinio distreso sindromas gali pasireikšti dèl plaučių hipoplazijos, tarpuplaučio poslinkio, spontaninio pneumotorakso ir vandenès sąlygoto skysčio pleuros ertmèje [17], o šio sindromo sunkumas priklauso nuo plaučių pažeidimo dydžio. Kliniškai kiekvienas atvejis kiek skiriasi - „kriokiančio“ kvejpavimo (angl. gunting ) sunkumu, tachipnèja, deguonies poreikiu - nuo nedidelio papildomo deguonies kiekio iki žaibiškai besivystančio kvėpavimo nepakankamumo, kai reikalingi agresyvūs ventiliaciniai režimai ar netgi ekstrakorporinè membraninè oksigenacija (ECMO). Dèl galimo tarpuplaučio poslinkio, gali nukentèti širdies, plaučiu funkcijos, vystytis spontaninis pneumotoraksas, susiformuoti oro spąstai. Galimos ir su plaučiu policistoze susijusios onkologinès ligos [15].

Vyresniems vaikams ir suaugusiesiems, kuriems chirurgiškai nepašalintos plaučių policistozès pažeistos plaučių dalys, pasikartojančių krūtinès ląstos infekcijų rizika išauga dèl bronchų suspaudimo, oro spąstų ir negebèjimo efektyviai pašalinti susikaupiančio sekreto. Plaučiuc policistoze sergantys asmenys gali atkosèti kraujo (paprastai vyresni vaikai ar suaugusieji), juos gali varginti dusulys ir krūtinès skausmas (kas taip pat gali būti ir spontaninio pneumotorakso klinikinè išraiška). Ligoniai gali skųstis ir kitais negalavimais: kosuliu, karščiavimu, gydytojai gali pastebèti sutrikusị vaiko vystymąsi. Dažniausi klinikiniai požymiai suaugusiesiems - pasikartojanti plaučių infekcija [17], pneumotoraksas, hemoptizè, karščiavimas ir dusulys $[5,12]$, gali būti diagnozuojama micetoma, bronchoalveolinè karcinoma [7] ar kita su plaučiu policistoze susijusi onkologinè liga.

Nuolatinè persistuojanti bakterinè infekcija skatina didesnę kvėpavimo takų sekreciją, bronchų obstrukciją ir bronchų deformaciją. Dèl šių pokyčių ar dèl didelio plaučių pažeidimo pasireiškia kvejpavimo nepakankamumas, plautinè hipertenzija ir lètinè plautinè širdis [1].

Fizinio tyrimo metu plaučiu policistozès požymiai nėra specifiški. Dažniausiai pastebima tachipnèja, gali būti trachejjos nuokrypis, kuris yra tarpuplaučio poslinkio ženklas, paprastai susijęs su pneumotoraksu, oro spąstais; netipiškose vietose girdimi širdies tonai, auskultuojant girdimas susilpnèjęs alsavimas pažeistoje plaučių pusejje; gali būti cianozè, pagalbinių raumenų dalyvavimas kvėpavime, gailus, kriokiantis kvejpavimas (angl. grunting).

Nors plaučių policistozė suaugusiesiems diagnozuojama retai, vis dèlto jos nereiketuc pamiršti diferencijuojant galimas pasikartojančio, nuolatinio neproduktyvaus kosulio priežastis suaugusiesiems.

\section{DIAGNOSTIKA}

\section{Prenatalinė diagnostika}

Gerejjanti echoskopinė diagnostika daugeliu atvejų leidžia igimtas plaučiu anomalijas diagnozuoti jau prenataliniu laikotarpiu, tačiau derètú nepamiršti, kad iki 56 proc. atvejuc pažeidimai iki gimimo regresuoja [11]. Tikimybè aptikti vaisiaus plaučių cistinị darinị ultragarsiniu tyrimu apie 18-20 néštumo savaitę yra beveik 100 proc. [19]. Tačiau plaučių policistozè neturi išskirtinių diagnostinių bruožų, leidžiančių vienareikšmiškai ją atskirti nuo kitų plaučių pažeidimų, pavyzdžiui, igimtos skiltinès plaučių emfizemos ar plaučiu sekvestracijos. Echoskopiškai galima pastebėti vandenę, pavyzdžiui, vaisiaus ascitą arba skystị pleuros ertmėse. I tipui būdingi 

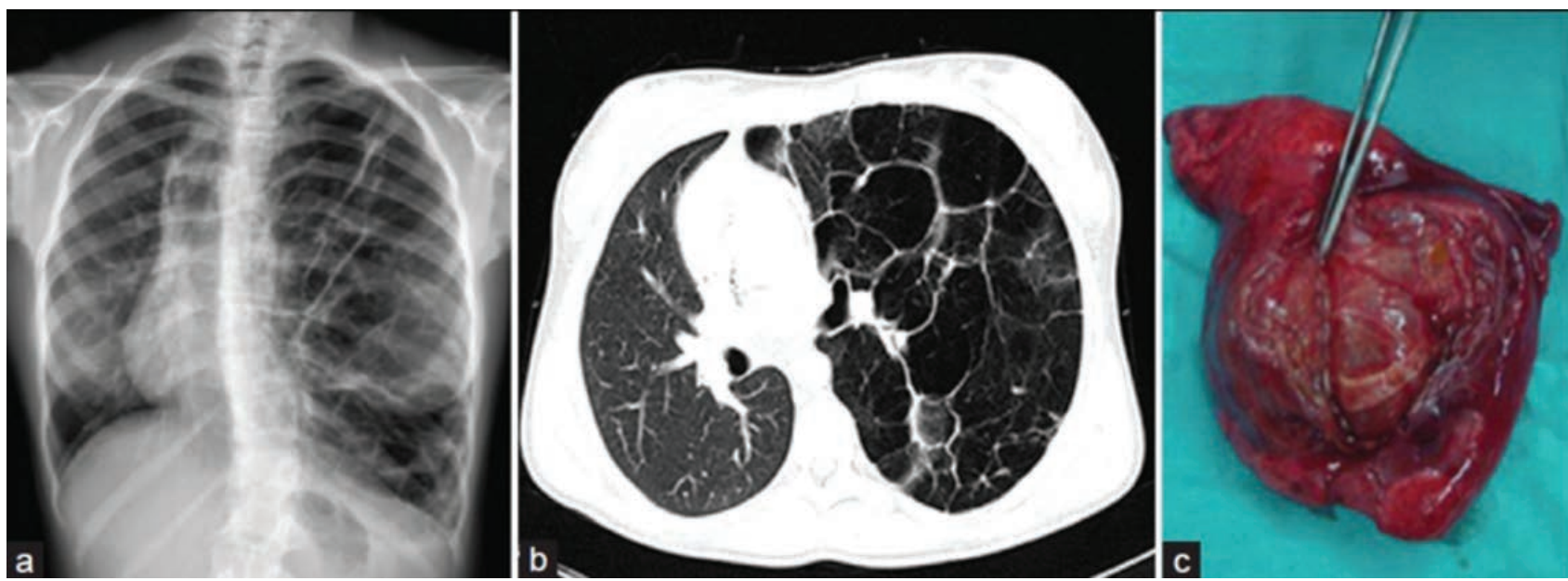

1 pav. I tipo igimta plaučių policistozè

Krūtinès lastos rentgenograma: daugybẻ oro prisipildžiusiụ cistụ su pertvaromis visoje kaireje krūtinės ląstos pusejje; tarpuplaučio poslinkis i dešinę (a). Krūtinès ląstos KT (plaučiu langas): țvairaus dydžio plonasienės, oro prisipildžiusios cistos (b), rezekuoto plaučio dalyje išsipletusios, su pertvaromis, skysčio prisipildžiusios cistinès masès (c) [45].

Odev K, Guler I, Altinok T et al. Cystic and Cavitary Lung Lesions in Children: Radiologic Findings with Pathologic Correlation. Review article. Journal of Clinical Imaging Science, 2013, 3 (4):1-10; internetine prieiga http://www.clinicalimagingscience.org/temp/JClinImagingSci3160-5316393_144603.pdf

pakitimai matomi kaip dauginiai dideli cistų pilni plaučiu plotai. II tipo pakitimai echoskopiškai matomi kaip daugybè mažų cistų. Dèl itin mažo dydžio cistų, esant III tipui, prenataliai atliekant ultragarsinį tyrimą, plaučių pažeidimas dažnai matomas kaip homogeniškai pakitusi plaučių sritis.

Tačiau motinos antsvoris, netinkama vaisiaus padètis, oligohidramnionas gali būti kliūtis echoskopiniam plaučių policistozès pažeidimų vertinimui. Ultragarsiniu tyrimu antenataliniu periodu gali būti kaidingai nustatyta kitų būklių (pvz.: igimtos diafragmos išvaržos, bronchų ir plaučių sekvestracijos, plaučių atrezijos, trachejjos atrezijos ir stenozès) diagnozè bei radiniai ịvertinti kaip plaučiu policistozès sąlygoti pakitimai, todèl prenataliniu periodu daugelio autorių rekomenduojamas diagnostinis tyrimas (ittarus plaučiuc policistozę ar anksčiau paminètas ligas) yra magnetinio rezonanso tyrimas, kuris padidina tikslesnès diagnozès ir tinkamo prognozès ìvertinimo galimybes [5, $20,21]$. Be to, yra pakankamai saugus: nei motinos, nei vaisiaus neveikia tokia jonizuojančioji spinduliuotè kaip atliekant kompiuterinę tomografiją.

Amniocentezès metu gali būti paimama amniono vandenų kariotipui nustatyti, tačiau chromosomu anomalijos, susijusios su plaučiu policistoze, labai retos.

\section{Diagnostika po gimimo}

Diagnostiką gali apsunkinti tyrimo metu plaučiuose esanti aktyvi infekcija.

\section{Radiologiniai tyrimai}

Radiologiniai radiniai priklauso nuo cistu turinio, dydžio ir skaičiaus.

Krūtinès ląstos rentgenograma. Atlikus krūtinès ląstos rentgenograma beveik visuomet galima ittarti plaučiu policistozę, jei ji pažeidusi pakankamą plaučių plotą, kad sukeltu klinikinius simptomus. Iprastiniai radiniai - daugybė ịvairaus dydžio oro ar oro ir skysčio prisipildžiusių plonasienių cistų. Gimimo metu cistos būna prisipildžiusios skysčio, kuri pakeičia oras cistoms turint ryši su trachebronchiniu medžiu ir vienom su kita. Vien skysčio prisipildžiusios cistos postnataliniu periodu gali būti pastebimos esant nepakankamai geram sekreto pasišalinimui iš apatinių kvẻpavimo taku iš apatinių kvėpavimo takų, kraujavimui ar antrinei infekcijai [9]. Kiti galimi radiologiniai ligos požymiai: tarpuplaučio poslinkis, skystis pleuros ir (ar) perikardo ertmèse, pneumototaksas.

Krūtinès ląstos kompiuterinè tomografija. Kai diagnozè nèra aiški iš plaučiuc rentgenogramos (matomi plaučių audinio pažeidimo plotai be cistu), atliekamas krūtinès ląstos kompiuterinès tomografijos tyrimas (rekomenduojamas daugelio autorių kaip pagrindinis diagnozuojant plaučiu policistozę po gimimo [20, 22, 23, 24, $5]$ ), kuris yra saugus ir padeda greitai ivertinti plaučiu policistozès pažeisto plaučiuc audinio plotą. Kompiuterinejje tomogramoje matomi pakitimai skiriasi priklausomai nuo plaučiuc poli-

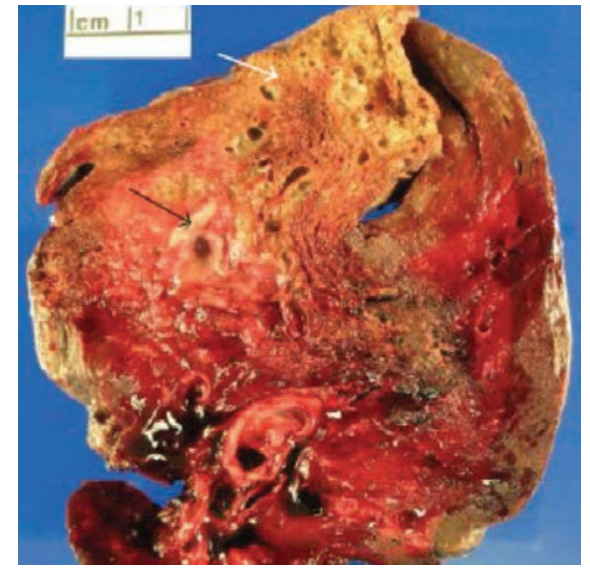

2 pav. Plaučių policistoze sergančio asmens rezekuota plaučio dalis

Baral D, Adhikari B, Zaccarini D et al. Congenital Pulmonary Airway Malformation in an Adult Male: A Case Report with Literature Review. Case Reports in Pulmonology, 2015 (2015), Article ID 743452, 6 pages $h t t p: / / d x$.doi.org/10.1155/2015/743452. Internetine prieiga http://www.hindawi.com/journals/ cripu/2015/743452/ref/ [5]

cistozès tipo ir klinikos. Tipiškas vaizdas yra daugiaertmiai cistiniai dariniai plonomis sienelèmis, apsupti normalios plaučių parenchimos, dažnai turintys oro ir skysčio paviršiuc. Didelès skiriamosios gebos krūtinès ląstos tomografija galima atskirti mikrocistas nuo makrocistų. Pagrindinis KT vaidmuo - atskirti šias cistas nuo bronchogeninių cistų, skiltinès emfizemos ar nuo sekvestracijos, siekiant tiksliai nustatyti pažeidimo ribas plaučiu segmentuose prieš numatomą chirurgini gydymą [9].

Tiek kairysis, tiek dešinysis plautis pažeidžiami vienodai dažnai, tačiau pastebèta, kad plaučių policistozė „la- 
biau mégsta" apatines plaučių skiltis ir vieną pusę (Stokker ir kt., 1988) [8]. Suaugusiesiems pastebima, kad plaučiuc policistozè būna dažniau pažeidusi abu plaučius (lyginant su vaikais) [25]

Sonoskopija. Visiems plaučiu policistoze sergantiems naujagimiams svarbu atlikti ir inkstų, smegenuc echoskopiją dèl galimų kitų anomalijų. Echokardiografiškai įvertinti, ar nèra širdies pažeidimo, o respiracinị distresą patyrusiems kūdikiams - ar nèra nuolatinès plaučių hipertenzijos (pavyzdžiui, nuosrūvio iš dešinès kairę, padidèjusio spaudimo plaučių arterijoje).

\section{Kiti tyrimai}

Laboratoriniai tyrimai plaučių policistozès atveju diagnostikos požiūriu paprastai nèra labai vertingi.

Bronchoskopuojant galima matyti siaurus bronchų spindžius, deformuotus, stenozuotus bronchus, ivairaus laipsnio pūlinị endobronchitą [1]. Histologinis tyrimas atliekamas iš plaučių audinio biopsijos ar rezekuotos dalies (paprastai vaizdo torakoskopijos ar torakotomijos metu) [26]. Kokie histologiniai pokyčiai būdingi kiekvienam ligos tipui aprašyta anksčiau. Plaučių arterijų angiografija rodo plaučiuc kraujotakos redukciją [1]. Diagnozès nustatymas paprastai užsitęsia tinkamai nenustatant pasikartojančios infekcijos, nuolatinio kosulio priežasties arba kai liga kliniškai nepasireiškia [7].

\section{GYDYMAS}

Dèl riboto ligos atveju skaičiaus plaučiuc policistozès gydymo gairès dar nèra suformuluotos. Dèl galimos piktybinès transformacijos ir pasikartojančios kvėpavimo taku infekcijos rizikos, esant nustatytai plaučiuc policistozès diagnozei ir klinikiniai ligos raiškai, dažniausia siūloma chirurginė pažeisto plaučių audinio rezekcija. Chirurginis gydymas yra esminis, iskaitant tiek vaisiaus operacijas, tiek postnatalinę chirurgiją. Vaisiaus chirurginio gydymo klausimas turi būti sprendžiamas tais atvejais, kaip plaučiu policistozès sąlygotas pažeidimas yra didelis, komplikuotas vandenès ir prognozè yra bloga [2]. Torakocentezès metu drenuojamos didelès cistos, tačiau dèl greito skysčio pakartotinio susikaupimo procedūros nauda menka [2]. Kitas vaisiaus chirurginio gy- dymo variantas yra torakoamnioninis šuntas, per kuri cistose esantis skystis nuolat nudrenuojamas $\mathfrak{i}$ amniono maišą. Ši procedūra naudingiaus esant didelèms, skysčio prisipildžiusioms cistoms, tačiau niekas neapsaugotas nuo galimų komplikacijų, pvz., šunto obstrukcijos ar poslinkio [2]. Pažeistos skilties rezekcija (lobektomija) yra chirurginio gydymo alternatyva tais atvejais, kai nèra dominuojančios cistos, kurią būtuc galima drenuoti. Postnataliniu periodu rekomenduojama visiems vaikams pašalinti plaučiuc policistozès pažeistus plaučių audinio plotus, siekiant sumažinti komplikacijų (pasikartojančių krūtinès ląstos infekcijų, pneumotorakso) riziką [9, 2]. Vaikams rekomenduojama šalinti visus cistinius darinius, sukeliančius simptomus, kad būtų išvengta komplikacijų, kurios vẻliau galètų komplikuoti operacini gydymą ir taip užkirsti kelią su plaučiuc policistoze susijusių onkologiniu ligu rizikai $[29,30]$. Vaikai, sergantys besimptome plaučių policistoze, diagnozuota iki gimimo, turi būti ilgokai stebimi neskubant operuoti, nes pažeidimo plotai dar gali labai sumažèti [20, 32, 33, 2]. Jei operacinis gydymas vis dèlto reikalingas, literatūros duomenimis, rekomenduojama ji atlikti iki kūdikiui sueis 12 mènesių. Tačiau, kokị operacinị būdą ir rezekcijos apimti parinkti skirtingo amžiaus ligoniams tebediskutuojama. Tradiciškai pirmenybė buvo teikiama lobektomijai baiminantis neradikalios pažeisto plaučiuc audinio rezekcijos [34] ir komplikacijų, pavyzdžiui, oro nutekejjimo, susijusių su plaučių audini tausojančiomis operacijomis [30]. Vyresniems pacientams trečdaliu atvejų nuolatinè pneumonija skatina atlikti išplèstinę plaučiu rezekciją [2]

Fascetti-Leon ir bendr. retrospektyvios apžvalgos duomenimis, plauti išsauganti rezekcija yra saugi ir veiksminga, nedidina ligos atsinaujinimo ar nevisiško pažeisto plaučių audinio pažalinimo rizikos, jei atliekama iš anksto gerai atrinktiems pacientams [35]. Bagrodia ir bendr. taip pat pateikia panašią išvadą, tačiau siūlo torakotomiją ir lobektomiją tais būtinais atvejais, kai plaučių rezervas ribotas ir yra didelès malformacijos [34]. Rezekuota plaučio dalis turi būti atidžiai vertinama dèl piktybinių pakitimų [29].

Pacientai, kuriems plaučių policistozè plačiai pažeidè abu plaučius, dažniausiai gydomi konservatyviai, nes jiems operacinis gydymas būtų labai rizikingas [15]. Diagnozė tokiais atvejais gali būti patvirtinta plaučiuc biopsija.

Nèra jokio specifinio plaučiu policistozès gydymo vaistais, išskyrus komplikacijų gydymą (pvz.: antibakterinis gydymas prisidejjus infekcijai (suaugusiems asmenims neretai nustatoma Aspergillus infekcija [25]), kvépavimo nepakankamumo gydymas nuo oksigenoterapijos iki plaučių ventiliacijos, ir pan.).

Besimptomès plaučiuc policistozès atvejais gydymas nèra gerai apibrèžtas. Kai kurie autoriai prieštaringai vertina operacini gydymą komplikacijuc profilaktikos tikslu ir mano, kad supiktybejjimo rizika yra pervertinta [12, 36]. Jie siūlo aktyvuc paciento stebejjimą, jei pacientas sutinka ir supranta galimas komplikacijas [36]. Be to, profilaktinè rezekcija ne visada visiškai apsaugo. Papagiannopoulos ir bendr. teigia, kad profilaktiné plaučių policistozès pažeistų plaučių audinio plotu rezekcija neapsaugo nuo vèlesnio pleuropulmoninès blastomos vystymosi [34]. Net ir po rezekcijos rekomenduojama aktyviai stebèti ligonius dèl onkologinių plaučių ligų.

Sergant plaučių policistoze, nèra mitybos ar fizinès veiklos apribojimų. Tačiau pacientai, kuriems pažeistos plaučių dalys nèra pašalintos (išlieka pneumotorakso grèsmè), turètų vengti veiklos, didinančios pleumotorakso išsivystymo riziką (pvz.: nardymas, kelionès lèktuvu).

\section{KOMPLIKACIJOS}

Su plaučių policistoze dažniausiai susijusios šios komplikacijos: nėštumo metu - priešlaikinis gimdymas, vaisiaus mirtis, gimus kūdikiui respiracinis distresas ir mirtis nepriklausomai nuo amžiaus (nors dažniau pasitaiko vyresniems vaikams ir suaugusiesiems - spontaninis pneumotoraksas, hemopneumotoraksas, hemoptize, pasikartojančios infekcijos, galimai su plaučiuc policistoze susijusi onkologiné liga (rabdomiosarkoma, plaučių blastoma, plokščiųjų ląstelių karcinoma, adenokarcinoma, broncholoalveolinè karcinoma [36]). Manoma, kad maždaug 1 proc. plaučiu policistozès atvejuc, ypač I ir IV tipuc, supiktybejja, nors tikslus dažnumas nežinomas [38]. Labiau linkusios su- 
piktybėti I plaučių policistozès tipo gleivinès ląstelès [39].

\section{DIFERENCINĖ DIAGNOSTIKA}

Tiriant vaikus plaučių policistozę reikia atskirti nuo igimtos pneumonijos, skysčio pleuros ertmeje, hemotorakso, vaiku igimtos diafragmos išvaržos, vaikų pneumotorakso, pneumocelès, plaučių sekvestracijos. Ligos, nuo kurių reikia atskirti plaučių policistozę tiriant suaugusiuosius:

- Plaučiuc sekvestracija - anomali plaučio dalis, nepriklausanti nuo viso plaučio, neturinti bronchu ir turinti anomalią kraujotaką ne iš mažojo kraujo apytakos rato kraujagyslès, o iš arterijos, atsišakojančios nuo aortos [10]. Plaučiuc sekvestraciją galima atmesti po radiologinio tyrimo, nes jai būdinga anomali sistemine kraujotaka iš krūtinès ar pilvo aortos, ne taip kaip plaučiuc policistozès atveju [2] Dažniausia klinikinė išraiška - pasikartojančios pneumonijos [37].

- Bronchogeninès cistos - kliniškai pasireiškia kosuliu, krūtinès skausmu. Atsiranda kaip nenormalus pumpuravimasis iš pirminio tracheobronchinio vamzdelio; plaučiuose lokalizuotos bronchogeninès cistos paprastai aptinkamos apatinèse plaučiuc skiltyse [27], vienoje pusèje, histologiškai randama bronchụ kremzlių, lygiųjų raumenu ir gleivinès liauku, tačiau šios cistos paprastai nesusijusios su bronchais, alveolèmis, o plaučiu policistozès cistos susijusios [28]), turi igytus cistinius pakitimus.

- Limfangiolejomiomatozé - reta liga, kai plaučiuose ima kauptis lygiųjų raumenų tipo ląstelès. Dažniausia klinikinè išraiška - pneumotoraksas. Būdinga, kad daugeliu atveju pasireiškia vaisingo amžiaus moterims. Cistos susiformuoja visais atvejais, išsidèsto difuziškai visame plaučių plote, yra panašaus dydžio ir taisyklingos formos [37].

- Plaučiuc Langerhanso ląsteliuc histiocitozè - reta, nežinomos etiologijos sistemine retikulohistiocitinio audinio liga, priklausanti granulomatoziu grupei ir pasireiškianti histiocitu proliferacija. Iprasta klinikinè išraiška dusulys, neproduktyvus kosulys. Dažniausiai serga rūkantys asme- nys. Cistos išsidèsto difuziškai, labiau "mègsta" viršutines plaučių skiltis, yra ịvairaus dydžio, keistos, netaisyklingos formos [37].

- Birt-Hogg-Dubé sindromas - kaip ir plaučių policistozé gali pasireikšti pneumotoraksu, bet kartu nustatoma ir inkstu onkologinè liga, odos pažeidimas. Būdingos ivairaus dydžio ir netaisyklingos formos cistos, išsidèstančios plaučiuose difuziškai bazaliai arba subpleuraliai. Kompiuterinèje tomogramoje matyti dauginès abipus subpleuraliai išsidèstančios plonasienès cistos [37].

- Limfocitinè intersticinè pneumonija - būdinga klinikine išraiška yra progresuojantis dusulys, kosulys; dažniausiai pasireiškia jungiamojo audinio ligomis (ypač Sjögreno sindromu) arba žmogaus imunodeficito viruso (ŽIV) infekcija sergantiems asmenims. Cistos išsidèsto dauginiais židiniais, yra įvairaus dydžio, netaisyklingos formos, išsidèsto perivaskuliariai. Kompiuterinejje tomogramoje matyti būdingi požymiai: „matinio stiklo“ zonos, centrolobuliniai mazgeliai, sustorèjusios pertvaros [37].

- Echinokokine infekcija - kliniškai pasireiškia dusuliu, kosuliu. Dažnai išsiaiškinama, kad pacientas buvo nukeliavęs ì Pietų Ameriką, Vidurio Rytus, Kiniją. Cistos ìvairaus dydžio, taisyklingos formos, išsidèsto pavieniai ar židiniais, ịprastai apatinèse skiltyse, gali būti pastebimas oro ir skysčio paviršius [37].

- Rečiau nei anksčiau išvardytais atvejais cistos formuojasi esant deskvamozinei intersticinei pneumonijai (30 proc. atveju), neurofibromatozès I tipui (25 proc.), Pneumocystis jirovecii pneumonijai (10-15 proc.), amiloidozei (reti atvejai) [37].

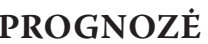

Blogos prognozės ženklai: prenataliniu laikotarpiu diagnozuota vaisiaus vandené, polihidramnionas $[15,32,2]$, mikrocistos plaučiuose [32,34], didelis bendras plaučiu pažeidimo plotas [2, $41,37]$. Sunku nustatyti ligos prognozę suaugusiesiems dèl besimptomių ligos atvejų, skirtingo plaučiu audinio pažeidimo masto, piktybinès transformacijos potencialo [14, 7]. Enuh ir bendr. aprašè plaučių policistozès, kurią komplikavo Aspergillus infekcija, atveji, kai mirè 59-erių metų vyras dèl masyvaus kraujo atkosejjimo ir išsivysčiusios diseminuotos intravaskulinès koaguliacijos lobektomijos metu [42]. Morelli ir bendr. aprašè atveji, kai mirè 38-metu vyras, sergantis plaučių policistoze, kuri vargino nuolatinis kosulys bei kraujo atkosejjimas, ir buvo atlikta lobektomija [43].

\section{STEBE்JIMAS}

Nèra visuotinai priimtos plaučiu policistoze sergančiuc pacientų stebejjimo taktikos. Sisteminant įvairių autorių pateikiamas rekomendacijas, šiems ligoniams periodiškai turi būti atliekama spirometrija, krūtinès ląstos radiologinis tyrimas (pirmenybè teikiama krūtinès ląstos kompiuterinei tomografijai). Taip pat nuolat stebima dèl infekciniu komplikacijų, kvejpavimo nepakankamumo ir simptominès obstrukcinès plaučių ligos [44], atliekami pagal klinikinę situaciją reikalingi tyrimai.

Parengè V. Žukauske

\section{CONGENITAL CYSTIC}

Keywords: congenital cystic lung malformation, children, adult.

Summary: Congenital cystic lung malformation is one of the most common malformations of the lower respiratory tract. This congenital abnormality of lung is usually diagnosed in the newborn or infancy and very rarely in adults. Therefore physicians for adults with less exposure to this pathology may unidentified disease or the initially care for such patients can be complicated. This article presents the essential aspects that must be known by the diagnosis, treatment and care of this congenital abnormality (both children and adults).

\section{LITERATŪRA}

1. Sfakianaki AK, Copel JA. Congenital Cystic Lesions of the Lung: Congenital Cystic Adenomatoid Malformation and Bronchopulmonary Sequestration. Rev mation and Bronchopulmonary Seque

2. Stone AE. Cystic Adenomatoid Malformation. Internetinè prieiga http://emedicine.medscape.com/ article/1001488-overview\#a5

3. Shanmugam G, MacArthur K, Pollock JC. Congenital lung malformations--antenatal and postnatal evaluation and management. Eur J Cardiothorac Surg. 2005 Jan. 27(1):45-52. [Medline].

4. Stanton M, Njere I, Ade-Ajayi N, Patel S, Davenport $M$. Systematic review and meta-analysis of the postnatal management of congenital cystic lung lesions. J Pediatr Surg. 2009 May. 44(5):1027-33. [Medline].

5. Baral D, Adhikari B, Zaccarini D et al. Congenital Pulmonary Airway Malformation in an Adult Male: A Case Report with Literature Review. Case Reports in Pulmonology, 2015 (2015), Article ID 743452,

Kiti literatūros šaltiniai (iš viso 45 ) redakcijoje. 